\title{
環境バランスエリアの創世に関する試論 一茨城県を対象としたケーススタディー
}

\author{
谷口 守 1 伊勢 晋太郎 2 - 陳 鶴 $^{3}$ ・村上 暁信 4 \\ ${ }^{1}$ 正会員 筑波大学大学院教授 システム情報系社会工学域（テ305-8573つくば市天王台1-1-1） \\ E-mail: mamoru@sk.tsukuba.ac.jp \\ 2非会員 東日本旅客鉄道(株) 長野支社総務部人事課（下380-0921 長野県長野市大字栗田源田窪992-6） \\ E-mail: ise-s@jreast.co.jp \\ 3学生会員 筑波大学大学院 システム情報工学研究科（†305-8573つくば市天王台1-1-1） \\ E-mail: chin.kaku@sk.tsukuba.ac.jp \\ 4非会員 筑波大学大学院准教授 システム情報系社会工学域（†305-8573つくば市天王台1-1-1） \\ E-mail: murakami@sk.tsukuba.ac.jp
}

\begin{abstract}
地球環境問題は深刻化の一途をたどり, 根本的に新しいアイデアを導入しなければその抜本的改善は期 待できない. 特に関係主体の行動を変えてしまうような新たな仕組みの発案が強く期待される。折しもわ が国では地方分権が進み，中央政府から自治体に降りてくる裁量と責任が，地球環境問題解決に向けて的 確に果たされる必要がある。本研究では自治体が自らの努力で環境バランスを達成すべく住民と行動する 上で参考となる新たな試論を提案する。具体的には環境バランス指標を達成するために, 市町村の再編と 財源の流動化をあわせて検討する仕組みを提示した。その評価指標にはエコロジカル・フットプリント指 標等を利用し，茨城県内の全44自治体に適用を行った。その結果，茨城県は16の環境バランスエリアと 10 の環境バランス未達成のエリアとに再編された.
\end{abstract}

Key Words : environmental balance, sustainability, ecological footprint, local government

\section{1. はじめに}

地球環境の現状を概観すると, $\mathrm{CO}_{2}$ 排出量や平均気温, 森林地面積などの主要な環境指標が経年的に悪化してい る ${ }^{1)}$ 。こうした状況を踏まえ，2012 年の 6 月下旬には国 連持続可能な開発会議（リオ+20）が開催されたが，深 刻化する環境問題に対して強制力のある取り決めが決定 されることはなかった2).

このような状況の一方で，わが国では地域主権改革 ${ }^{3)}$ などの地方分権に向けた法整備が進んでおり，各市区町 村（以降，自治体）の裁量が今後更に大きくなると予期 できる. したがって，環境問題に対する自治体レベルで の取り組みが, 環境問題解決のためにより重要となる. また，自治体の裁量と同様に責任も大きくなっており， まず財政面での独立採算制が以前よりも厳しく問われる ようになってきている．持続可能性の達成という視点か ら, 将来には自治体内で発生する環境面での負荷につい ても，責任をもって自治体内で受容する，いわゆる環境
負荷の地産地消（環境バランス）がより求められるよう になることが否めない，しかし，そうした時代が到来し たとしても，各自治体がそれぞれ単独で環境バランスを 達成するのは実情としても，またその仕組みとしても現 状では極めて困難と考えられる. なお, 総務省 ${ }^{4}$ )では, このような広域化する行政課題への取り組みを進める方 法として，市町村合併や広域行政の必要性を述べている. 以上のような社会変化の方向性に鑑み, 本研究では 「環境面での独立採算制」ともいうべき全く新たな視点 から地域を見ることを試みる，具体的には，我々の日常 的な生活圈である身近な自治体が，環境バランスという 観点からどれだけその要件を満たしているのかを明らか にする「仕組み」を提示することを目的とする．住民の 直観にも訴えるわかりやすい仕組みにするために, 環境 バランスを圈域として成立させる環境バランスエリアと いう新たな「コンセプト」をまず提案し，その存立を定 量的に検討するための道具として環境負荷を示す「指標」 と環境受容を示す「指標」を導入する. その仕組みとし 
ては，環境負荷が相対的に高い都市域が，どこまで環境 受容量の高い周辺地域まで取り込めば環境バランスを達 成できるようになるかを判断するものである．具体的に は市町村のスケールで, 環境負荷を表現寸る指標と環境 受容を表現する指標の比率を求める事を通じてそれぞれ の環境バランスを明らかにする．都市的要素の強い環境 負荷の高い市町村が，環境受容力の高い非都市部の市町 村をどのように合併していけば，環境バランスが改善さ れていくかを確認する。このような検討プロセスを通じ, 環境面での持続可能性に関する地域住民の理解を高める とともに, 改善行動につながる将来的な制度のあり方を 模索する.

\section{2. 益獣としてのゲリマンダ一復活}

当たり前の事であるが，「環境面」だけに着目した自 治体などというのは現実的には存在し得ない.ただここ のような単一機能に着目した地域区分というのは有史以 来特定の局面で検討の対象とされてきた事は事実である. その中でも特に有名なものは図-1 に示すゲリマンダー であろう。これは，1812 年，マサチューセッツ州知事 であったエルブリッジ・ゲリー氏が，自分の所属する政 党に有利なように選挙区を区割りした結果，その形が怪 獣のサラマンダーに似たことを挪揄して命名されたもの である5

利己的な政治的理由からこのような地域区分がなされ るのは，もちろん社会的に望ましいことではない，また， 単一機能のみに着目して地域区分を考えると, 往々にし てこのようないびつな形ができるということをこのゲリ マンダーは示唆している. 本研究では他要素を混在して 議論すると主眼とする環境バランスの検討が不明確とな るため, 他を固定して, 環境という単一機能のみの影響 を切りだして検討する事を目的としている. このため, 周辺地域の取り込みを通じて提示される圈域像はゲリマ ンダー化することが予想される．ただ，その目的は過去

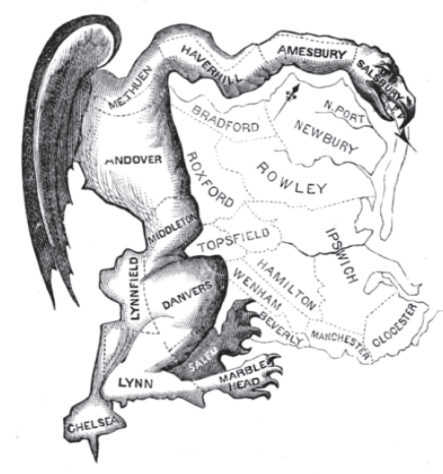

図-1 ゲリマンダー0
のゲリマンダーと異なり, 環境バランスの実際を知ると いう極めて公益性の高い動機に基づくものである.この ため, 本研究の遂行は地域計画の中で政治的歪曲によっ て本来悪獣として生まれたゲリマンダーを, 環境バラン ス確認のための益獣として命を吹き込むという意味をも 有している.

以上を踏まえ本研究では, 後述するエコロジカル・フ ットプリント(EF)指標とバイオキャパシティ(BC)指標を 用いた環境バランスエリアという新たな圈域設定のコン セプトを提案する. 更に, この概念を用いた環境バラン ス改善方策として，環境バランスエリア提案制度の仕組 みを構築する。この制度は, 各自治体に対して環境バラ ンスを達成する圈域の提案を促すことで, 現状における 環境バランス改善と, 環境バランス達成に向けた行政圈 の設定を同時に実施することができるものとする．また， 茨城県の全 44 自治体を対象にケーススタディを行うこ とで, 制度実施における課題を抽出する.

\section{3. 既存研究のレビューと本研究の位置づけ}

\section{(1) 既存研究のレビュー}

近年ではエコロジカル・フットプリント指標（以下， EF 指標）が着目されており，わが国でも政策レベルで の活用方法が検討されている 7,8). $\mathrm{EF}$ 指標は, 人間活動 に伴う食糧消費や $\mathrm{CO}_{2}$ 排出, 都市活動に必要な土地利用 等々，様々な環境負荷を土地資源の消費面積（Footprint） に換算することで, 同一基準によって包括的に評価でき る指標である. さらに, それら環境負荷量に対して対象 とする都市・地域内の環境受容量(農用地や $\mathrm{CO}_{2}$ 吸収の ための森林地等々)がどの程度存在するのか, 持続可能 性の観点から，それら環境バランスを比較できる.

EF の活用事例としては，国家レベルでは WWF によ って，世界約 150 力国の $\mathrm{EF}$ 指標值を算出した ${ }^{9}$. また, 都市・地域レベルにおいても，ロンドン (イギリス) ${ }^{10)}$, サンチアゴ (チリ) ${ }^{11}$ など, 数多くの事例が世界各地で 見られる.このように国家・地域レベルでの環境負荷と 受容量を算出し，そのバランスを評価することで，持続 可能な地域づくりに向けての具体的な施策を検討するこ とが可能である. また, EF 指標の計画分野への活用を 目的とした研究も数多く見られる. 例えば, 都市基盤整 備の差異と EF 指標值の関係の研究 ${ }^{22}$, 車利用抑制のた めのソフト施策の実施における環境負荷削減効果を, EF 指標を用いて算出する研究 ${ }^{13)}$, 資源の不均衡配分を $\mathrm{EF}$ 指標で明らかにした研究 ${ }^{14)}$ ，さらに， EF 指標を用い た地域間キャップ\&トレード制度の提案 ${ }^{15}$ などは行われ ている.

圈域に関する理論的研究は, クリスタラーの中心地理 
論16など，旧くより行われている．わが国では，戦後， この中心地理論の紹介を契機に圈域構成の研究が盛んに なったが，当初は地域実態の分析が主であった ${ }^{17}$. その 後, 圈域設定の計画論を行政的に初めて公準化した新全 国総合開発計画 ${ }^{18}$ の策定を受け，その前後に計画の方法 論としての研究に発展した. 特に行政圈の設定方法に関 しては, 行政圈の課題を指摘 ${ }^{1920)} し$ ，それらを整理した もの21) や，農産物の自給的な範囲に注目したもの 22 , 自 治的なまとまりに注目したもの 23 , 归村を重要な単位と 寸るもの ${ }^{24}$ など, 様々な研究が為されている. その後, 通勤・通学流動に基づく行政圈の設定手法を提案した研 究 ${ }^{25} や$, 盆地を基礎とした行政圈の妥当性を分析した研 究 ${ }^{20)}$,さらに行政圈域が地理的・歴史的要因に裏打ちさ れながら各種施設・サービス圈域の外輪として大きな役 割を果たすという関係があることを明らかにした研究27 が行われている.

一方，近年深刻化する環境問題に対する圈域に関する 検討事例としては, 河川の流域を一つの環境を考慮した 圈域としてみな寸流域環境圈 ${ }^{28)}$ や, 地理的に異なった特 徵的な生態系の集合を含む圈域としてWWFによって提

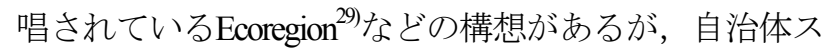
ケールでの環境問題への取り組みに対寸るインセンティ ブを含んだ仕組みではない，また，そのスケールでの多 様な環境負荷が起因寸る問題を包括的に捉えたものでは ない.

\section{(2) 本研究の特長}

以上を踏まえ，本研究の特長を以下にまとめる.

1) 自治体圈域のあり方を環境バランスという視点か ら問い直す新規性に富んだ試みである。このよう な価值観に基づく検討は現時点ではまだその重要 性も社会的に十分認識されていない。しかし，今 後発生しうる資源の枯渇やエネルギー価格の高騰 を想定すれば，事前に検討しておくことが必要な 取り組みであるといえる.

2）環境複合指標の中でも個人の諸活動によって発生 する環境負荷の積み上げを面積で表現できるEF指 標を採用している. その利点としてその地域の実 際の環境負荷受容量と同一次元で環境バランスの 実態を数值として簡便に把握することができ，住 民が自分の活動を見直すうえで最も直観的で，か つ活用可能な有用性の高い仕組みの提案が可能と なる.

3) 数值をどう積み上げるかということはブラックボ ックス化せずに公開パッケージとしている．今後 個別の地域レベルでの検討がより詳細に進んだ場 合は，関連するパラメータ值を差し替えることが できるようにしており，その仕組みとしての汎用
性と信頼性を確保している.

4) 国土計画や土地利用計画を見直すうえで，環境バ ランスに依拠した検討のニーズは高まっていくと 考えられ, 今後の発展・応用可能性も高い取り組 みであると考える。

\section{EF指標値（環境負荷量）とBC指標値（環境受 容量）の算出方法}

本研究でのEF值の算出は，Ujihara Taniguchi Model 2010.3 (EF-Calc) $)^{30}$ に基づいている. 本ツールでのEF指標值は, 土地利用計画などを策定する際に重要な関連性のある下 記要素より構成されている，また，これらの算出式を表 -1に示す.

1) 食料, 動物飼料, 衣料のための作物生産に必要と なる耕作地

2)食肉, 牛乳, 毛糸のための動物に必要となる牧草 地

3）製紙材料を採取するための森林地

4) 都市的な活動を提供するために必要な土地

5)排出された二酸化炭素を吸収するために必要な森 林地

上記はいずれも実際の居住者の生活を支える上で必要 な土地の面積である. なお，1)，2)，3)，5)についてはそ れぞれ原単位的な発想をべースにその算出を行うが，4) の都市的な活動用地については, 実際のその市町村にお

表-1ＥF指標の各構成要素の算出式

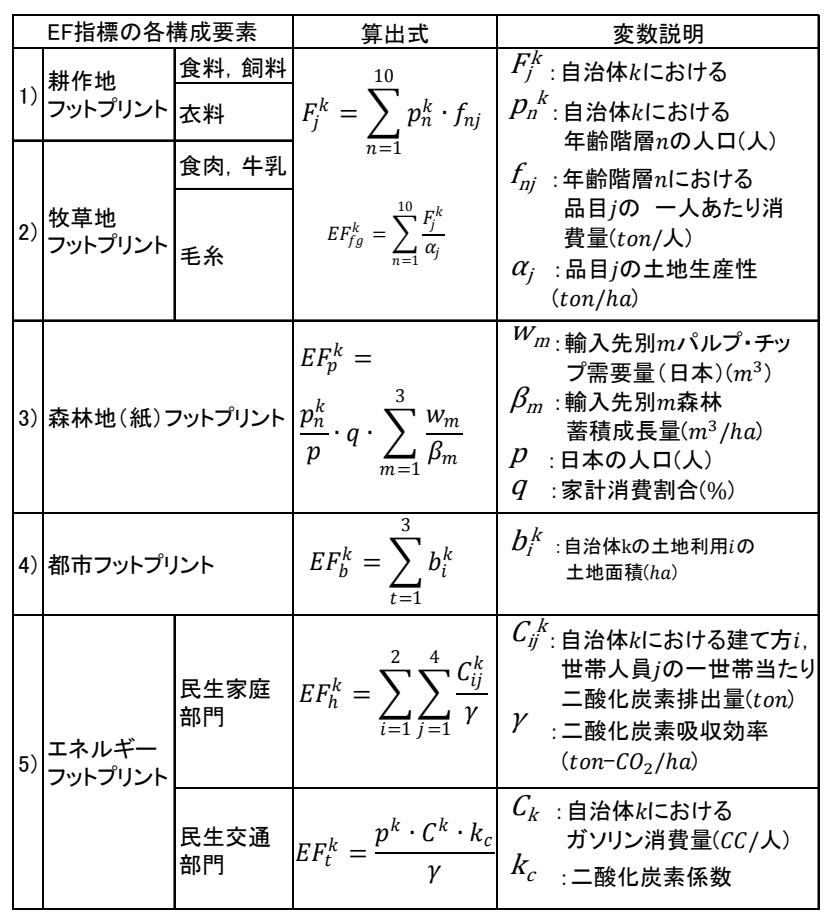


ける都市的土地利用の面積を知ることができるため，そ の值をそのまま用いている，一方， BC指標值は，EF指 標值の各構成要素を受け入れるための実際の土地利用面 積である.このため，4)についてのみ，今回の方法では 計算上EF指標值と BC指標值が同一值になる４4)のEF指 標值については現在よりもさらに建物を高層化するとい った空間効率利用のメニューを今後加えていくことが可 能である.

更に, EF指標值及びBC指標值に基づく環境負荷超過 率を定義する.この超過率は，「地域の環境受容量に対 して, その地域から発生する環境負荷量がどの程度ある のか，それらのバランスを示寸定量的な指標」15)である。 自治体kに対する環境負荷超過率 $\left(r^{k}\right)$ は以下のように 定義されている.

$$
r^{k}=\frac{E F^{k}}{B C^{k}}
$$

$E F^{k}$ : 自治体 $k$ の居住者消費に伴う $\mathrm{EF}$ 指標值(ha)

$B C^{k}$ : 自治体 $k$ $\fallingdotseq \mathrm{BC}$ 指標值 $(h a)$

このとき， $r^{k} \leq 1$ となる自治体が，環境負荷と環境受容 の環境バランス（以降，環境バランス）を達成している と判断する. また本稿では, $r^{k}>1$ となる自治体を, 他地 域に環境負荷を依存している自治体として，「依存自治 体」，そうでない自治体を「非依存自治体」と定義する。 同時に，環境バランスが達成されたエリアを，「環境バ ランスエリア」とする.

このツールを用いることで，地域内における居住者の 日常生活に伴って発生する環境負荷を対象としたEF指 標值を手軽に算出寸ることが可能となる．そのEF指標 值と, 地域内の環境受容を対象としたBC指標值を把握 することで, 住民の暮らしから発生する環境負荷, そし て地域内における環境バランスの実態を明らかにするこ とができる.

このようなアプローチで分析することで，各地域住民 は自らの生活を直接の原因とする環境負荷の実態と環境 バランスの現状を把握することが可能となる，それはす なわち, 地域住民の自覚に基づく行動変容を通じた環境 バランス改善への第一歩として必要不可欠な情報となる なお，地域における工場などから生じる環境負荷は，そ の地域居住者の日常生活によって発生寸る環境負荷には 該当しないため，分析の対象外としている.

\section{5. 環境バランスエリア提案制度の方法論}

\section{（1）本制度の考え方}

環境バランスエリア提案制度の肝となるそのエリアの 組み立ては，域内に存在する非依存自治体と，そこに隣 接する複数の依存自治体のいずれかが合併することを通
じ，広くなった依存自治体の環境負荷超過率を下げてい くというプロセスから構成される.ここで, 非依存自治 体がいずれの依存自治体と合併するかは数多くの考え方 が存在し，従ってそれらの組み合わせの場合の数も単純 に考えれば膨大である.

本稿ではまずその考え方の基本として，人口などの都 市規模が大きい一般的に発言力が相対的に高いと考えら れる自治体が合併を通じて得られる環境改善の利得を独 占するのではなく, 対象圈域全体の構成自治体がいずれ も納得できる共通ルールに基づくことが必要であると考 えた. さもなくば，そもそも構成自治体が本制度の導入 に合意できないからである。 そしてなおかつ最も効果的 に各依存自治体の環境負荷超過率を下げて行く必要があ る.

以上のことから，本稿では依存自治体がその周囲の非 依存自治体と合併寸るにあたり，他の競合する依存自治 体がその非依存自治体と合併寸るよりもより自らの環境 負荷超過率をより下げる事が出来るかどうかを判断基準 とした。わかりやすく言えば，環境バランスを達成でき ていない依存自治体A市とB市があり, 既に環境バラン スを達成している非依存自治体C市の取り合いになった 場合，合併を通じて環境負荷超過率の削減割合がA市の 方がB市より大きいのであれば，A市とC市の合併を優先 すべきであるという考え方である.このプロセスを繰り 返し，それ以上構成自治体の環境バランスを改善できな いところで解が得られる.

また，域内の環境負荷超過率が絶対的に全体に高い場 合は，そこに属する依存自治体が $r^{k} \leq 1$ となる環境バラン スエリアを達成できるとは限らない．環境バランスの判 断基準とする環境負荷超過率を1.0に固定する限り, こ の問題の解決は難しい. そのような地域に対しても適用 可能な制度とするため, 環境負荷削減目標として本研究 では $\alpha$ 值というものを設定する.この值は, その地域 の実態に応じ, 努力次第で達成可能な環境負荷超過率に 相当する. そして，依存自治体はその值を達成すること を目標に隣接する非依存自治体を吸収していくものとし た．このとき，以降はこの $\alpha$ 值を環境バランス達成の基

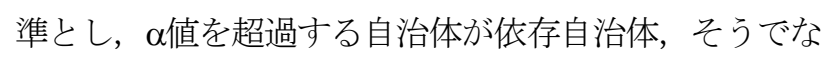
い自治体が非依存自治体と呼び直すこととする.

\section{(2) 分析手順}

本研究で構築する環境バランスエリア提案制度の手順 を図-2に示寸.

まず図-2の【1】において, 各自治体のEF指標值と BC 指標值を算出する.これにより, 自治体毎の環境負荷超 過率を把握でき, 各自治体個々の環境バランス達成状況 が明らかになる. 寸なわち, 環境バランスを達成できて いない依存自治体の存在をまずクリアにする. 
次に【2】において，依存自治体は環境バランスエリ アを周辺の非依存自治体を取り込むことを通じて提案す る.この際，取り込み方にも様々なメニューが考えられ， 例を挙げれば，自らの環境負荷超過率をより下げる非依 存自治体を取り込んだり，地理的なメニューとして鉄道 沿線上の自治体を通過順に取り込んだり, 更には隣接し ていない非依存自治体を取り込むといった考え方もあり 得る. これらのメニューに従うことで, 依存自治体が他 の依存自治体を取り込むことも考えられる．このように， 各依存自治体は多様な環境バランスエリア案を提案する ことが可能である.

一方で, 前述したように, 議論の前提としていずれの 自治体も納得できる共通ルールに基づくことも必要であ ると考える．したがって本稿では，その取りこみにより， どれだけ大きく自らの環境負荷超過率をより下げる事が 出来るかどうかを吸収の判断基準とする.このプロセス を通じて依存自治体は吸収寸る非依存自治体に対して環 境負荷超過率の下げ幅に応じた報酬を支払うこととする また, 最終的に環境バランスエリアの達成に至らなかっ た依存自治体には，一定のペナルティを課すことをあわ せて想定する．なお，このペナルティは上位自治体であ る県におさめることとする.

このような仕組みを取ることで【3】において，結果 的に，依存自治体には報酬およびペナルティの支払い額 を小さくするために，また非依存自治体には報酬の受け 取り額を大きくするために，それぞれの自治体内で環境 バランス改善のインセンティブが発生する. 本制度では, 各自治体が環境バランスの達成を目標に, 上述した

【2】，【3】を繰り返すことを想定する.

なお，仕組みとしては報酬やペナルティのやり取りの みでとどめ, 環境バランス圈域として新たな行政域の設 定まで行わないという考え方ももちろん存在する．本稿 ではあえてそれを冒頭で述べたゲリマンダーのように空

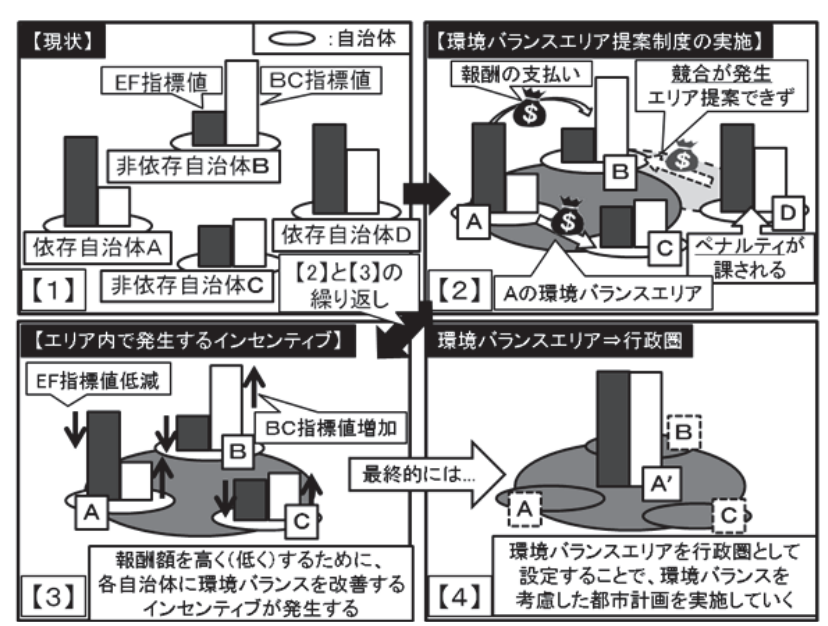

図-2 環境バランスエリア提案制度のフレームワーク
間範囲として提示することで, 自治体関係者および住民 が環境の観点から維持管理責任を持つ空間範囲として認 識されることに意義があると考える.

\section{（3）報酬額の算出方法}

本制度が実施された場合，依存自治体はそのエリア内 の非依存自治体に報酬を支払う，その報酬額の算出につ いては, 既存研究 ${ }^{31}$ を参考に, 環境負荷を吸収する土地 の「地代」を根拠に設定する．以下にその算出式を示寸。

$$
\begin{aligned}
& P^{k l}=\left(E F^{k}-E F^{k} \cdot \sum_{l=1}^{p} \frac{E F^{l}}{B C^{l}}\right) \cdot L R \\
& \text { ただし, } r^{k}>r^{l} \Leftrightarrow \frac{E F^{k}}{B C^{k}}>\frac{E F^{l}}{B C^{l}}
\end{aligned}
$$

$P^{k}$ : 依存自治体 $\mathrm{k}$ の自治体 $l=\{1, \cdots \cdot, p\} \frown の （$ 総）支払 金額（円/年）

$L R:$ 1ha あたりの地代（円/年）

地代の算出には地価に対して社会的割引率（0.04）を 乗じることで算出した．また，1ha あたりの地価に関し ては山林素地平均価格（用材林地及び薪炭林地：平成 23 年平均) ${ }^{31)}$ 用いた.

\section{(4) ペナルティ}

本制度の運営にあたって，依存自治体の中には環境バ ランスエリアを形成できない自治体も存在すると考えら れる. そのような依存自治体に対してはペナルティを課 すことで，各依存自治体には制度への参加及び，環境バ ランス改善のインセンティブが発生する.

本制度の本来の目的は, 行政圈での環境バランス達成 である.したがって，依存自治体の提案するエリア内の 環境負荷超過率が $\alpha$ 值を達成できなかった場合には，ペ ナルティとしてその自治体が他自治体に依存している全 ての環境負荷量（ha）を金額に換算して支払うことを義 務付ける.このようなある種のバンキング・システム ${ }^{32)}$ を採用し，上位自治体である県がその管理・運営を請け 負い，広域的観点から環境バランス改善に資する基盤整 備等の予算に充当する. 式(2)を参考に, 以下にその算 出式を示寸.

$$
F_{n}=\left(E F_{n}-B C_{n}\right) \cdot L R
$$

$F_{n}:$ 依存自治体 $n$ のペナルティ金額（円/年）

\section{6. ケーススタディ}

本章では，前章で構築した制度によって，依存自治体 からどのような環境バランスエリアが提案されうるのか を把握するために，ケーススタディを行う. 


\section{(1) 分析対象域}

本ケーススタディの分析対象域として, 本研究では環 境バランスに影響を及ぼす都市活動と地域環境の面で, 多様な特徵を有する茨城県内の全44自治体を対象とする。 茨城県は首都圈外縁部に位置し県北部は山林が多い一方 で，県南部では鉄道沿線上で開発が進んでいる.

この茨城県内の全自治体を対象に，3章で説明した環 境負荷超過率を算出した結果が図-3である。この図表か ら以下のことが明らかとなった.

1) 県内の全自治体の環境負荷超過率の平均值が2.92, 中央值が3.27となった. 日本の環境負荷超過率の平 均值が2.50（環境白書 : 平成17年） ${ }^{33) て ゙ あ る た め, ~}$ 茨城県における環境バランスの達成度は相対的に 低いことが分かる。

2)県内で環境負荷超過率に偏りがあることが分かる. 先述の通り，近年開発が進んだ県南部の超過率が 高い，一方で，森林地といったBC指標值の要素が 相対的に多い県北部では超過率が低い.

\section{（2）つくば市を例とした検討}

まず，全自治体のケーススタディを行う前段階として， 各自治体がどのような環境バランスエリアを提案する可

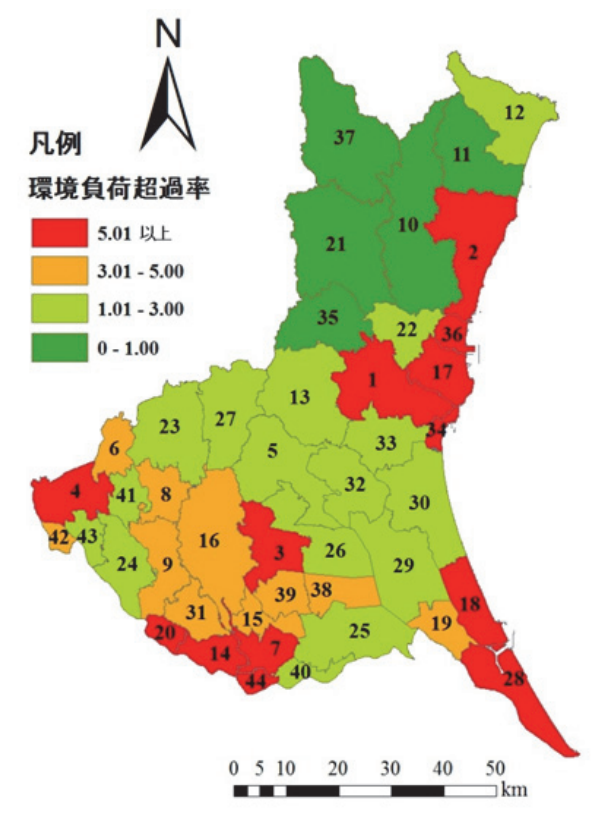

\begin{tabular}{|l|l|l|l|}
\hline \multicolumn{5}{|c|}{ 凡例: 図中番号対応自治体 } \\
\hline 1.水戸市 & 2.日立市 & 3.土浦市 & 4.古河市 \\
\hline 5.石岡市 & 6.結城市 & 7.龍ケ崎市 & 8.下妻市 \\
\hline 9.常総市 & 10.常陸太田市 & 11.高萩市 & 12.北茨城市 \\
\hline 13.笠間市 & 14.取手市 & 15.牛久市 & 16.つくば市 \\
\hline 17.ひたちなか市 & 18.鹿嶋市 & 19.潮来市 & 20.守谷市 \\
\hline 21.常陸大宮市 & 22.那珂市 & 23.筑西市 & 24.坂東市 \\
\hline 25.稲敷市 & 26.かすみがうら市 & 27.桜川市 & 28.神栖市 \\
\hline 29.行方市 & 30.鉾田市 & 31.つくばみらい市 & 32.小美玉市 \\
\hline 33.茨城町 & 34.大洗町 & 35.城里町 & 36東海村 \\
\hline 37.大子町 & 38美浦村 & 39.阿見町 & 40.河内町 \\
\hline 41.八千代町 & 42.五霞町 & 43.境町 & 44.利根町 \\
\hline
\end{tabular}

図-3 茨城県内全自治体における環境負荷超過率の現
能性があるかを把握しておく必要がある。そこで，近年 開発が進んだ県南部で最も人口が多いつくば市（環境負 荷超過率は4.26）を例として，その吟味を行う.

この試案ではつくば市が単独で環境バランスエリアを 構築しようとするため, 他自治体との競合は発生しない ただ単に周囲の非依存自治体を順番に取りこんでいくと いうことになる．実際に順番に周囲の非依存自治体を取 りこんでいった結果，環境バランスがまだ達成されてい ないにもかかわらず，図-4に示す状況で吸収できる自治 体が無くなってしまう

この状況での新たなつくばエリアの環境負荷超過率は 1.28 である. なお，この試行の結果生まれた新たなつく ばエリアの形状は一つの自治体として見るには非常に広 く，このような形で無理に絶対的な環境バランスを達成 しようとすることは必ずしも望ましいことではない.こ こでは方法論において記述したとおり，当面の環境バラ ンス目標值として 1.0 よりも緩和した環境負荷超過率を 導入し，更に検討を進めることとする． $\alpha$ 值の設定には 多様な考え方があるが，ここでは 3.27 (県内全自治体の 中央值）に設定する。この值の下では，つくば市は 図-5 のような環境バランスエリアを提案することにな る.

一方，前章でも述べた通り，非依存自治体の取り込み 方にも様々なメニューが考えられる，そこで，本節では 引き続きつくば市を例に，いくつかのメニューを設定す ることで出来る環境バランスエリア案を検討していく. そのエリア案が図-6〜図-8である.これらの図に関して，

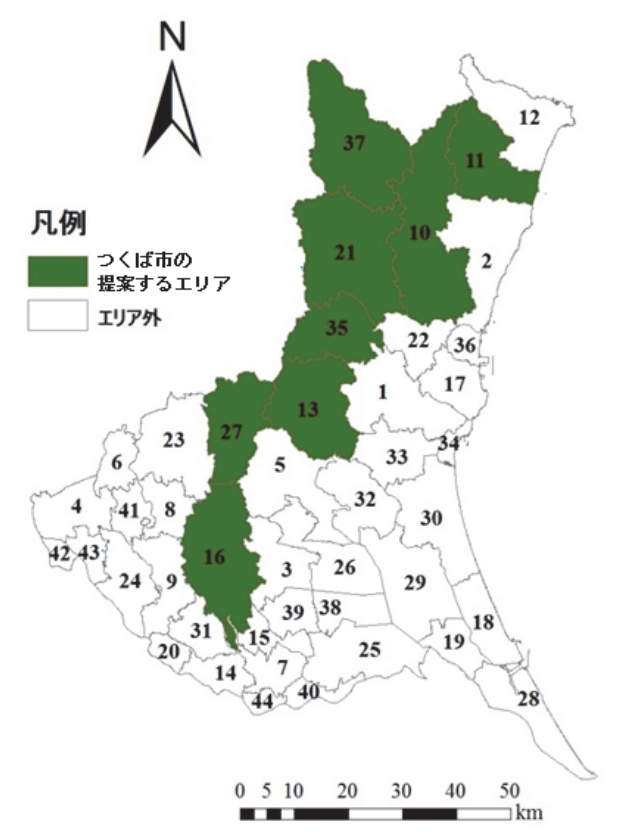

図-4 つくば市が環境バランス達成を目指したエ リア案（最も環境負荷超過率を下げる隣接 自治体を取り込む.しかし，環境バランス 


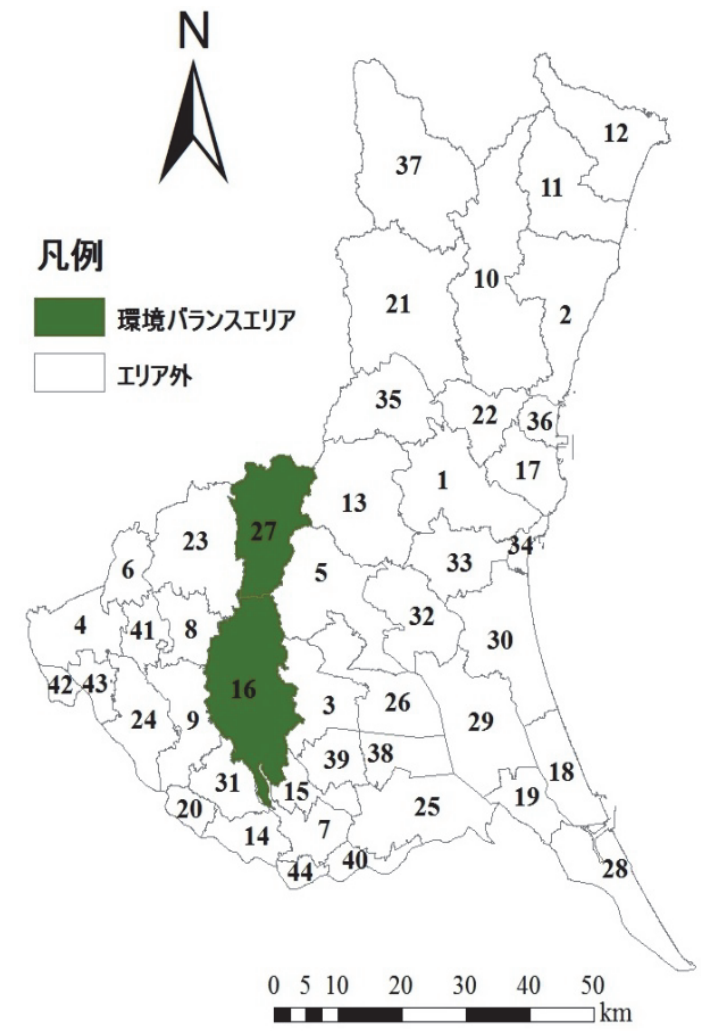

図-5 つくば市の環境バランスエリア案（ $\alpha$ 值を 3.27 に緩和後, 隣接する自治体の中で環境負荷超 過率を最も下げる自治体を取り込む)

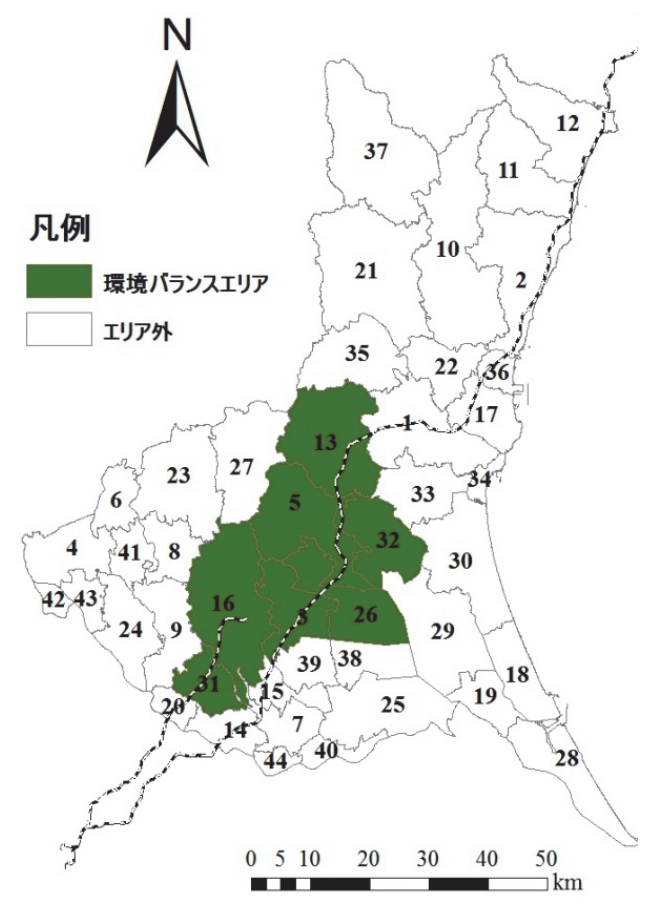

図-7 つくば市の環境バランスエリア案（ 值を 3.27 に 緩和後，つくば市及び土浦市を起点とした鉄道 沿線上の自治体を取り込む)

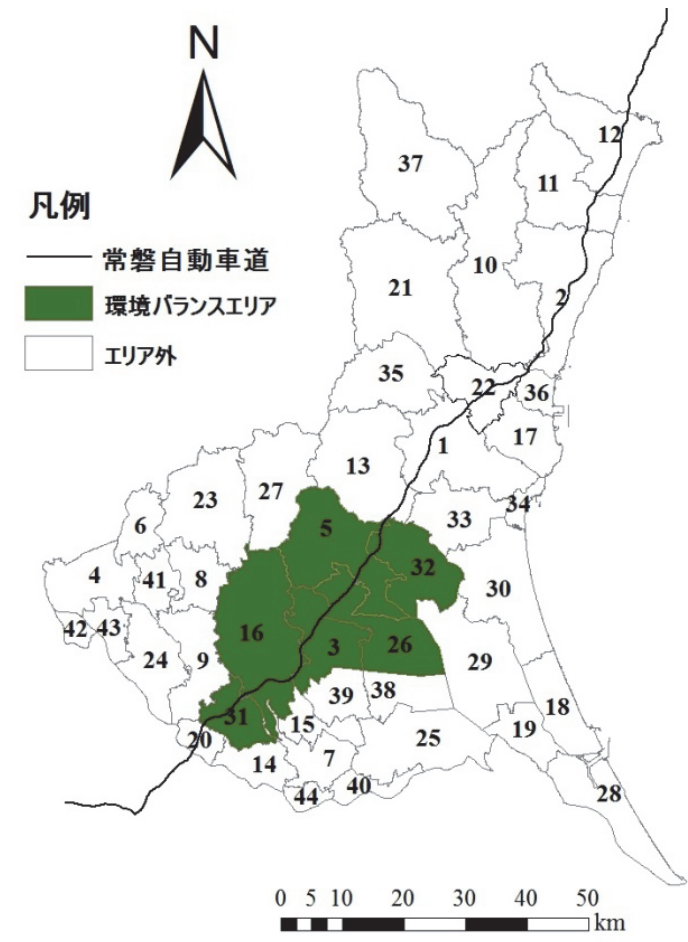

図-6 つくば市の環境バランスエリア案（ $\alpha$ 值を 3.27 に 緩和後，つくば市を起点とした常磐自動車道沿 線上の自治体を取り込む)

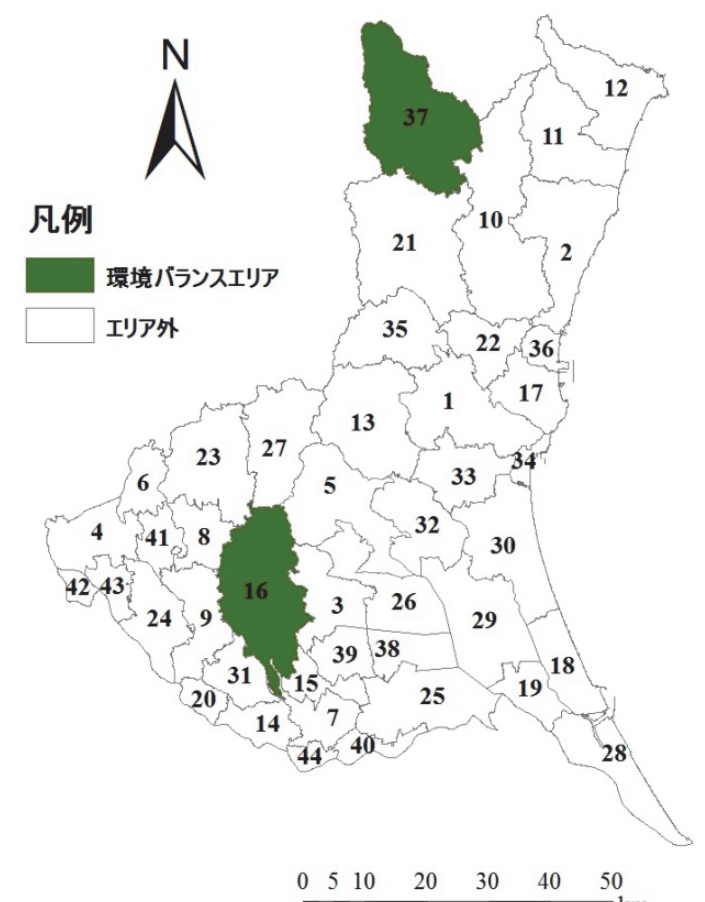

図-8 つくば市の環境バランスエリア案（ $\alpha$ 值を 3.27 に緩和後, 環境負荷超過率を最も下げる 自治体を取り込む) 
1) まず，図-6はつくば市を通る常盤自動車道沿線上 の自治体を，その通過順に取り込むことで環境バ ランス達成を目指したものである。ただし，通過 順に取り込むために，依存自治体である土浦市も 取り込むことで，環境負荷超過率が上がってしま っている。しかし，通過順に自治体を取り込むこ とで， $\alpha$ 值を達成した環境バランスエリア案が提案 できた.

2) 次に，図-7は，10\%通勤圈に含まれるつくば市及び 土浦市を起点とする鉄道沿線上の自治体を通過順 に取り込むことで環境バランス達成を目指したも のである，これは，既存の圈域を環境バランスの 観点から評価したとも言い換えることができ，環 境バランスエリア概念の更なる活用可能性が示唆 できた。また，つくば土浦通勤圈を環境バランス の観点から評価すると，環境負荷を吸着しきれず， 不十分であることが示された.

3) さらに，図-8は茨城県内で環境負荷超過率を最も 下げる自治体を取り込むことで環境バランス達成 を目指したものである. これは特殊な例ではある が，メニュー次第では環境バランスエリアが飛び 地になることも想定できる.

4) 隣接し，環境負荷超過率を最も下げるという基準 だけでなく，上述したような日常生活に密接に関 わるメだけでなく，上述したような日常生活に二 ューを設定することで，より地域住民の生活スケ 一ルに関わりがあると考えられる環境バランスエ リア案を提案できる可能性が示唆された。このよ うにして提案されたエリア案を検討することで,

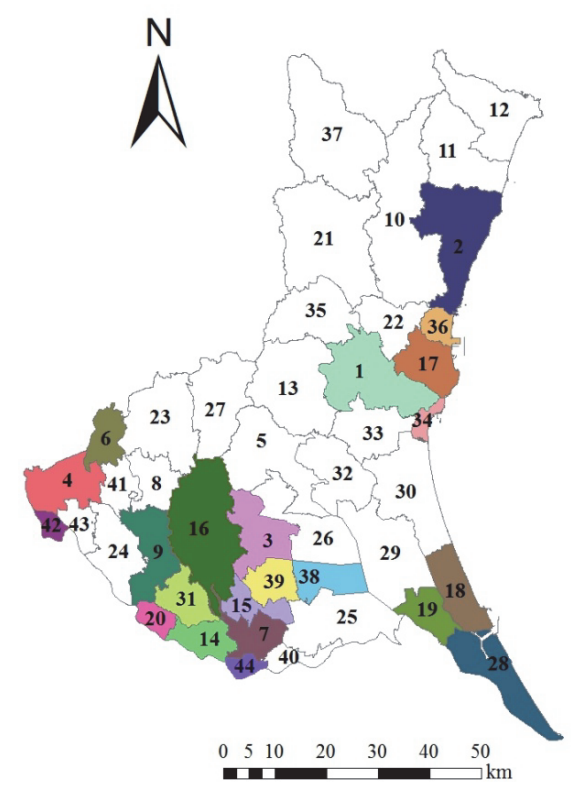

図-9 茨城県内の環境バランスエリア提案自治体（着 色の22自治体)
住民の生活圈などに配慮したものとして，自治体 圈域への適用が可能となると考えている.

\section{（3）茨城県を例とした検討}

以下では自治体間の競合も考慮した形で，茨城県全自 治体を対象としたケーススタディを行う。まず， $\alpha$ 值を 3.27 に設定した場合，茨城県において $\alpha$ 值を超過してい る依存自治体は，図-9 に示す 22 自治体である.これら の自治体がエリア提案自治体となる.

これらの自治体が前章で構築した手順に従って制度に 参加した場合の結果として，茨城県における環境バラン スエリア案を図-10，各エリア提案自治体が支払う報酬 額を図-11 にそれぞれ示す. 地域の取り込み方の手順と しても先述しているが，再掲すると，環境バランスを達 成できていない依存自治体 $\mathrm{A}$ 市と B 市があり, 既に環 境バランスを達成している非依存自治体 C 市の取り合 いになった場合，合併を通じて環境負荷超過率の削減割 合が $\mathrm{A}$ 市の方が $\mathrm{B}$ 市より大きいのであれば，A市と C 市の合併を優先すべきであるという考え方に基づいてい る.これらの図から以下のことが明らかとなった。

1) 図-10 から，本ケーススタディによって茨城県の全 44 自治体は，16の環境バランスエリアと，10の環 境バランス未達成のエリアとに再編された．前者 には 31，後者には 13 の自治体がそれぞれ取り込ま れたことになる．茨城県南部の東京に近いところ で未達成エリアが多くなっている，広域行政の観 点から市町村合併が行われてきたが，環境バラン スの観点からみると，目標值を中央值に緩和した 水準から見ても，現状の行政域では不十分である

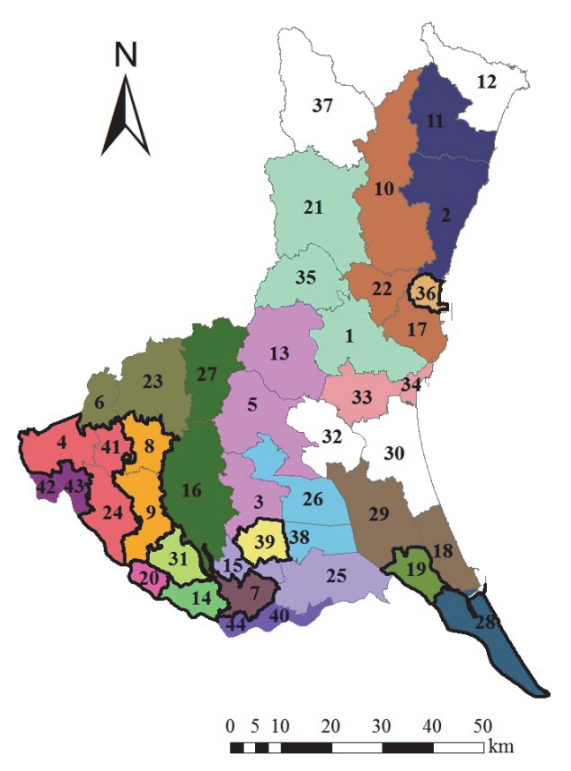

図-10 茨城県内全自治体の環境バランスエリア案 (黒太枠内は環境バランス未達成のエリア) 
ことが示された. 一方，この環境バランスエリア 案をそのまま自治体圈域として考慮するにはまだ 課題がある．実際に適用を行っていくうえで住民 の生活圈や歴史的経緯などにも配慮を行っていく 必要は当然存在する.

2) 図-11に示したとおり報酬額に関しては，総額 2000 億円以上が自治体間及びペナルティとして県内を 循環することが明らかとなった。この金額は，茨 城県の全自治体に㧍ける一般会計予算総額の約 $20 \%$ に相当する. 各自治体にとっても十分な環境 バランス改善のインセンティブになると考えられ る.

この報酬は，環境負荷超過率の下げ幅に応じて，エリ ア内の依存自治体加非依存自治体一と支払われる。こ の報酬の使途に関して，本制度の目的を考慮すると，環 境バランス改善に資する基盤整備等に用いられることが 望ましい.

\section{7. おわりに}

本研究では圈域の一つの概念として, 環境負荷量が環 境受容量を越えない環境バランスエリアというコンセプ トをはじめて提示した。 また，面積計算を通じて簡便に 積算でき，政策論的意味づけにも展開が容易な環境負荷

$0.0 \quad 50.0100 .0150 .0200 .0250 .0300 .0350 .0$ (億円)

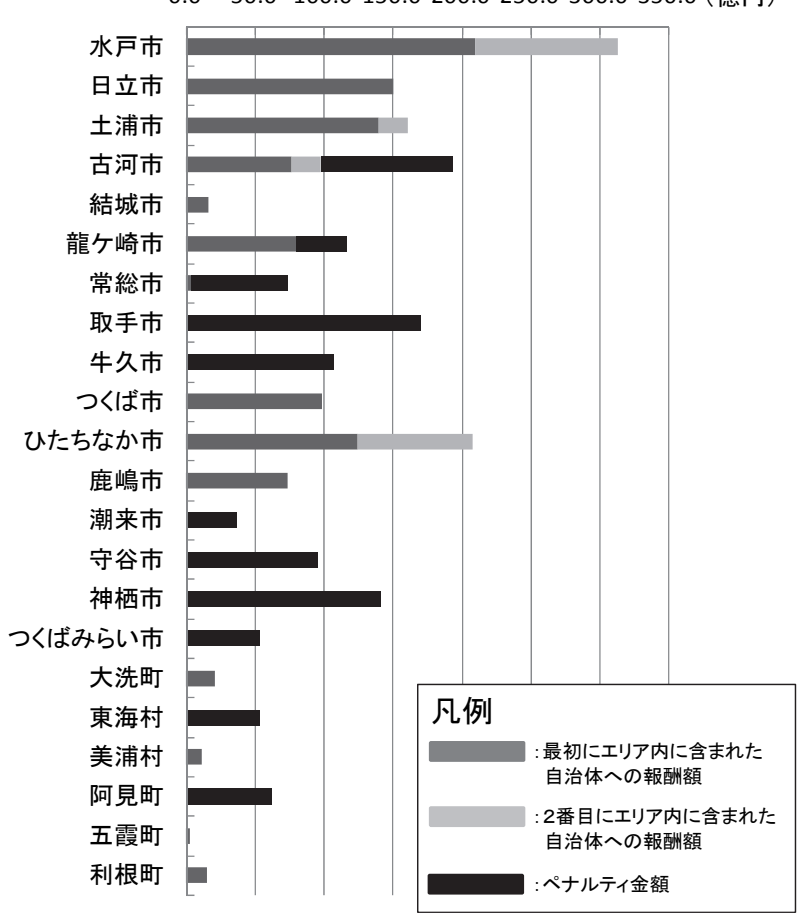

図-11 茨城県内全エリア提案自治体が非依存自治体に 支払う報酬額一覧
指標としてエコロジカルフットプリント指標を採用し， 茨城県を対象に実際に環境バランスエリアの設定を行っ た.さらに依存自治体が非依存自治体を取りこんでいく にあたり，緩和される環境負荷に応じた報酬を支払う仕 組みを設定し, 広く環境バランス改善のインセンティブ が住民にも行政にも及ぶ仕組みを考案した。

実際の適用を行ったところ, 本研究で提案する環境バ ランスを実際に達成するのははるかに隔たった状況であ ることがまず確認された，その上で，たとえば県全体の 環境負荷超過率の中央值を用いることにより，より住民 の生活スケールや行政の財政スケールに呼応した形での

「疑似」環境バランスエリアの設定がありうることを具 体的に提示した.

更に，日常生活に関わるメニューを用いて環境バラン スエリア案をいくつか提案した. この概念を発展させる ことで，地域住民の生活圈や歴史的経緯などに配慮した 自治体圈域の適用が可能となると考えている.

なお，本研究ではデータ制約上，現在の自治体の存在 をまず前提とし, 基本の分析単位として選しでいる. 住 民の本来の日常生活圈等を考えると, より細かなたとえ ば集落などのゾーンから積み上げるという形でエリア設 定を考えることが必要であろう.ペナルティを地代の全 額を充てるという考え方も今後の改良の余地があると考 える、また，今回のケーススタディでつくば市が遠郊部 までを含んでも環境バランスを達成できなかった。この ことからも明らかなように, 本制度の適用は県スケール よりも道州スケールなど, 今後の行政単位にも対応した さらに広いスケールでの適用がより望ましいものと考え られる。

謝辞 : 本研究の実施に際して, 岡山大学大学院環境学研 究科の氏原岳人助教に資料の提供や有益なご示唆を頂い た. なお, 本研究の実施に際し, 公益信託エスペック地 球環境研究・技術基金の助成を得た．記して謝意を申し 上げる.

\section{参考文献}

1) 本間仁, 安芸皓一: 物部水理学, pp.430-463, 岩波書 店, 1962 .

2) United Nations Environment Programme: Keeping track of our changing environment, 2012.

3) 外務省：国連持続可能な開発会議（リオ+20）, http://www.mofa.go.jp/mofaj/gaiko/kankyo/rio_p20/gaiyo. html, 2013.2 最終閲覧

4) 内閣府：地域主権改革, http://www.cao.go.jp/chiikishuken/, 2013.3 最終閲覧

5）総務省：広域行政・市町村合併, http://www.soumu.go. jp/kouiki/kouiki.html，2013.2 最終閲覽

6) 平凡社：世界大百科事典, 第 2 版, 2006. http:// redistricting.lls.edu/why.php より転載，2014.2.22 最終閲覧 
7) 国土交通省：持続可能な国土管理専門委員会, http://www.milt.go.jp/singikai/kokudosin/keikaku/jizoku/3 /jizoku_shiryou.html, 2013.3 最終閲覧

8）環境省：平成 24 年環境白書, pp.9.

9) WWF : LIVING PLANET REPORT 2012 : http://www. wwf.or.jp/activity/lib/lpr/wwf_lpr_2012.pdf, 2013.7 最終 閲覧

10) Best Foot Forward: City Limits A resource flow and ecological footprint analysis of Greater London, 2004.

11) Chambers, N., Simmons, C. and Wackernagel, M.: Sharing Nature's Interest, 2000. (邦訳 : 五頭美和訳 エコロジカ ル・フットプリントの活用地球 1 コ分の暮らしへ, 合同出版，2005.)

12) Barrett, J. and Scott, A.: An Ecological Footprint of Liverpool: Developing Sustainable Scenarios, Stockholm Environment Institute, Stockholm, 2001.

13) Birch, R., Wiedmann, T. and Barrett, J.: The Ecological Footprint of Greater Nottingham and Nottinghamshire, Results and Scenarios, 2005.

14) Duro, J. A. and Figueras, J. T.: Ecological footprint inequality across countries: The role of environment intensity, income and interaction effects, Ecological Economics, Vol. 93, pp. 34-41, 2013.

15) 氏原岳人, 谷口守, 松中亮治：エコロジカル・フッ トプリント指標を用いた環境負荷の地域間キャップ\& トレード制度の提案—“身の丈にあった国土利用” に向けた新たなフレームワークの構築一, 都市計画 論文集，No.43-3，pp.877-882， 2008.

16) Christaller, W.: Die Zentralen Orte in Süddeutschland, Jena, 1933.

17) たとえば, 渡辺良雄 : 地方サービス圈, 福島盆地, 東北地理 6, 1953 .

18) 国土交通省 : 新全国総合開発計画

19) 石田頼房 : 地方都市圈計画をめぐる論点と今後の課 題，都市計画，No.82，日本都市計画学会， 1975 .

20) 加藤幸雄 : 市町村区域の再編成と旺盛, 地域開発 4, 日本地域開発センター, 1975.

21) 吉阪隆正 : 圈域的計画論 新しい地域計画の視点, 農 林統計協会, 1981 .

22) 西山卯三：国土形成の一試論, 地域空間論, 勁草書
房, 1968.

23）渡辺光雄，青木志郎：農村の基礎生活圈の構造につ いて，日本建築学会論文報告集，No.199，1972.

24）中島熙八郎, 中林浩, 西沢恒善, 広原盛明 : 農山村 地域における重層的自治生活圈域構成論, 京都府丹 後地区広域市町村圈振興整備構想に関する研究(その 1): 都市計画, 学術講演梗概集, 計画系 51(計画系), pp.1161-1162, 社団法人日本建築学会, 1976.

25) 吉武哲信, 橒木武, 河野雅也, 天本徳浩 : 地域間流 動を用いた圈域設定法とそれに基づく圈域構造の把 握，都市計画論文集，No.23，pp.307-312， 1988.

26）藤芳隆也, 後藤春彦, 吉田道郎 : 盆地を基礎とする 圈域設定に関する基礎的研究, 盆地の外部依存度の 定量化と自立性の評価, 日本建築学会計画系論文集, No.512, pp.167-173, 1998.

27) 徳田光弘, 友清貴和 : 歴史的変遷から見た行政圈域 と施設・サービス圈域の関係，生活圈域と市町村合 併の整合性から見た圈域設定手法に関する研究 その 1, 日本建築学会計画系論文集, No.586, pp.65-72, 2004.

28）筒井信之：流域環境圏を基にこの国の形を創る，樹 林舎, 2010 .

29) WWF: ECOREGIONS, http://worldwildlife.org/biomes, 2013.2 最終閲覧

30) 氏原岳人, 古市佐絵子, 白戸智, 谷口守 : エコロジ カル・フットプリント指標に基づく自治体レベルの 環境バランス評価一実践計算パッケージ「EF-Calc」 を用いて一, 第 38 回環境システム研究論文発表会講 演集, pp.245-251，2010.

31) 日本不動産研究所 : http://www.reinet.or.jp/, 2013.3 最 終閲覧

32) State of California Resources Agency Department of Fish and Game: California Wetland Mitigation Banking, http://www.dfg.ca.gov/hadon/conplan/mitbank/Wetlands\% 20Bank\%20Leg\%20Report\%202005.pdf, 2013.3 閲覧

33) 環境省: 平成 17 年環境白書

34) Hale, N., Benjamin and Russell, J.: Federalist Newspaper, 1812.

(2014. 2. 28 受付)

\section{THE GENESIS OF ENVIRONMENTALLY BALANCED AREAS - CASE STUDY IN IBARAKI PREFECTURE-}

\section{Mamoru TANIGUCHI, Shintaro ISE, He CHEN and Akinobu MURAKAMI}

New ideas must be implemented to slow the progress of severe global environment problems. Especially, a new system to alter behaviors of respective economic and environmental actors is highly anticipated. Because decentralization continues to devolve power from the national government to local municipalities, appropriate systems are necessary for governments to fulfill their responsibilities with decision making related to global environment problems. This study proposes the basic idea that municipalities should maintain environmental balance in each territory by their own efforts. Therefore, municipalities' finances and merging should be evaluated according to a balance index. The Ecological Footprint index is introduced for this evaluation to examine how territories and finances are affected by such a system. Application of this system to 44 municipalities in Ibaraki prefecture reveals 16 balanced areas and 10 unbalanced areas. 